\title{
My Sons Have Defeated Me: Walter Lippmann, Felix Adler, and Secular Moral Authority*
}

\author{
Sarah Imhoff / Indiana University
}

In his 1929 A Preface to Morals, American journalist and political philosopher Walter Lippmann wrote, "Modern man who has ceased to believe, without ceasing to be credulous, hangs, as it were, between heaven and earth, and is at rest nowhere." The secular Lippmann located the source of this feeling of unmooredness in the particulars of modernity, where the religions of the past were no longer credible, but men (and also, although not in an identical way, women) still sought something to believe in. If the acids of modernity - in his famous phrase- had dissolved the worldviews that made religions plausible, they had not dissolved the human needs that religion had fulfilled.

Despite their otherwise often disparate outlooks, Felix Adler, Reform rabbi turned founder of the Ethical Culture movement, would have agreed. Unlike Lippmann who spoke mainly to an elite that had already become cognizant of the homelessness of their belief, ${ }^{2}$ Adler set out to convince his readers that traditional religions had neither met the spiritual needs nor offered the proper tools of moral cultivation in modern America. Likewise noting the shortcomings of both "heaven" and "earth," Adler wrote that both "the economist" and "the moralist" had "failed in the crisis. Humanity cried out loudly

\footnotetext{
* I am indebted to Clark Gilpin, Loren Goldman, Kathryn Lofton, Eva Mroczek, and the anonymous reader for their insight and suggestions. I am also indebted to Clark Gilpin for much more than the inspiration for this essay and for much more than space here allows me to express.

${ }^{1}$ Walter Lippmann, A Preface to Morals (1929; New Brunswick, NJ: Transaction, 1999), 9.

${ }^{2}$ In Preface to Morals, Lippmann made this thought explicit: "This is the first age, I think, in the history of mankind when the circumstances of life have conspired with the intellectual habits of time to render any fixed and authoritative belief incredible to large masses of men" (12). Likewise, in a review of Harold Laski's The Problem of Sovereignty, he called for political concepts to be "reexamined as fearlessly as religious dogmas were in the nineteenth century." In making this comparison, Lippmann disclosed that he thought the most significant and spectacular moments of discrediting religious "dogmas" had passed; quote in Heinz Eulau, "From Public Opinion to Public Philosophy: Walter Lippmann's Classic Reexamined," American Journal of Economics and Sociology 15 (July 1956): 441.
}

(C) 2012 by The University of Chicago. All rights reserved.

0022-4189/2012/9204-0007\$10.00 
enough through its depths, but neither had an adequate answer."3 These two men, the secular Lippmann who downplayed his Jewish heritage and the religious reformer Adler, both diagnosed American society with the same illness: the culture lacked a convincing account of who or what held moral authority.

The question of the location of moral authority - written scripture or oral teaching, individual or communal, in the celestial or earthly realms-has recurred throughout Jewish and Christian history. A well-known Talmudic story encapsulates the way traditional rabbinic culture conceptualized this problem but also helps shed light on some of the questions about moral authority that plagued Jewish thinkers of all stripes, such as Lippman and Adler, into the modern, secularizing age. In the story, Rabbi Eliezer and the other rabbis have a disagreement about whether or not a certain oven is ritually pure. In order to demonstrate the correctness of his position, Eliezer calls out to heaven three times, and three miracles occur. ${ }^{4}$ The other rabbis refuse to accept these miraculously uprooted carob trees, reversed rivers, and leaning study-house walls as valid halakhic (legal) arguments. Finally a heavenly voice says, "Why do you dispute with Eliezer when the halakhah agrees with him?" Rabbi Joshua retorts, "God gave us the Torah at Sinai. We pay no attention to heavenly voices because we follow the Torah, where you wrote: incline after the majority." Sometime later, a rabbi met Elijah and asked him about the incident: "What did the Holy One, Blessed be He, do that time we had that big disagreement over the oven?" Elijah told the rabbi, "God laughed and said: "My sons have defeated Me, My sons have defeated Me." The laughter hints that God knew both the futility and the power of Joshua's move. Although humans seemed to have grabbed religious authority for themselves, they would always find this authority slipping through their own fingers. If religious law resided on earth, and human decision making trumped divine decree, then humans would have to come face to face with a staggering level of moral responsibility and continually renegotiate religious authority.

Eliezer, of course, was not so easily defeated. Although Joshua's position won out in the midrash, the history of Judaism has been much more complicated. The age-old contest between Eliezer to Joshua describes an enduring set of options, which many generations have engaged. What made this question seem so pressing - and so distinctive for Lippmann and Adler in the

\footnotetext{
${ }^{3}$ Felix Adler, The Reconstruction of the Spiritual Ideal (Hibbert Lectures) (New York: Appleton, 1924), 3 .

${ }^{4}$ Baba Metzia 59a-b. The issue seems to be about an oven made of separate tiles rather than one large piece. Eliezer holds that because neither the individual tiles nor the sand between them is a utensil, the oven is not liable to impurity. The other sages say that the structure as a whole is a utensil because of its unified exterior, and therefore it is subject to impurity. Many scholars have interpreted this text in its rabbinic context. See, e.g., Jeffrey Rubenstein, Talmudic Stories (Baltimore: Johns Hopkins University Press, 1994), 34-63; Daniel Boyarin, Intertextuality and the Reading of Midrash (Bloomington: Indiana University Press, 1994), 33-34; Susan Handelman, Slayers of Moses (Albany: SUNY Press, 1982), 40-41; David Stern "Midrash and Indeterminacy," Critical Inquiry 15 (1988): 132-62.
} 
1920s? I argue that two dramatic cultural developments lent particular urgency to the question: the Great War and its aftermath, and women's suffrage and rights. The sheer scale of the first war-with the number of developed countries, sizable armies, and newly destructive military technologiesforced humans to consider how fully they held the power of life and death. Persistent discourse about women's rights and suffrage compelled Americans to consider the foundations of their ideas about gender roles. Were women political beings? Domestic selves? Inherently more moral than men? And where did they look to know the answers?

The connection between these seemingly incommensurable thinkers demonstrates how the dramatic cultural events of war and women's rights focused attention on the shifting sands of moral authority. In these texts, Lippmann and Adler both want to leave Judaism behind (although in different ways and for different reasons), but in doing so they must struggle with the evaporation of any solid external locus of moral authority.

Lippmann and Adler were surely not the only thinkers considering the issue of moral authority in the early twentieth century. Other American Jewish intellectuals, especially those who were religious, also struggled with the implications of Torah lo be-shamayim he (Torah is not in heaven). There were the Reform rabbis who had celebrated the scientific study of the Bible as a product of humans. These rabbis embraced the freedom to discern ethical acts without being beholden to every facet of scripture. There were also those more traditional Jews who grappled with interpreting the authority of halakhah in the context of modernity. Walter Lippmann and Felix Adler, two of Rabbi Joshua's least likely intellectual heirs, also found themselves pondering questions about the locus of moral authority, if not through the medium of rabbinic texts. As Jews who rejected normative Judaism, Lippmann and Adler nevertheless occupied themselves with the task of locating moral authority in a universe where the Torah was decidedly not in heaven. In the 1920s, both embarked on journeys to find secular moral authority that was both philosophically and practically germane to American life.

The intellectual biographies of the two men could hardly have been more different. Adler was seventy-two years old when he published The Reconstruction of the Spiritual Ideal in 1923. He was the son of the famous German rabbi Samuel Adler, and his family assumed he would grow up to follow in his father's footsteps. Instead the talented young Adler left Judaism after giving his first sermon at his father's large Reform synagogue, Temple Emmanuel in Manhattan. Even though he no longer associated himself with Judaism, he remained a major figure in New York religious circles through his Ethical Culture movement. ${ }^{5}$ Adler had long felt that the time of the universal moral utility of the bible had passed, but he still sought to create a spiritual

\footnotetext{
${ }^{5}$ Benny Kraut focuses on religious thought and development in his biography of Adler; From Reform Judaism to Ethical Culture: The Evolution of Felix Adler (Cincinnati: Ktav, 1979).
} 
community that would look to a variety of traditional texts for usable ideas. ${ }^{6}$ Even given his rejection of Judaism, Adler and his thought played a significant role in Jewish religious thought and dialog in the United States.

Lippmann was of a younger generation than Adler; he was thirty-three years old when Public Opinion was published in 1922. Lippmann was born into a middle-class German Jewish family in America and became a bar mitzvah, but he sought to downplay his Jewishness at every turn and studiously avoided association with other groups of Jews. Even though he attended Harvard, he supported its notorious Jewish quotas. On the rare occasion he broached the topic of Jews in print, he located the fundamental factor not in "Henry Ford or any real belief in the nonsense about world conspiracy and the so-called "protocols," nor in theological or economical realms. Rather, the "real fountain of anti-Semitism" was "the rich and vulgar and pretentious Jews of our big American cities," according to Lippmann. ${ }^{7}$ In addition to his feelings about Jews, Lippmann generally saw the influence of religious institutions declining, a situation he considered inevitable. ${ }^{8}$ As bastions of tradition, they were holding onto a model of moral authority that could no longer hold sway with modern men and their experience. His training at Harvard launched him into the orbit of the philosophers William James, George Santayana, and Graham Wallas. His professional training came largely in the field of journalism and politics, where he sought to influence the American intellectual and political climate through his essays, columns, and work with politicians. ${ }^{9}$

In the historiography, Lippmann sits among political philosophers, journalists, and public intellectuals. ${ }^{10}$ Adler occupies a place in the narratives of liberal and reformist American religious traditions, Progressivism, and liberal Judaism. ${ }^{11}$ While Adler maintained deep relationships within the Jewish

\footnotetext{
${ }^{6}$ In 1905, Adler wrote: "The Bible used to be in the old days all-sufficient . . . , and it still is, in part at least, an admirable aid for those who know how to use it." Adler believed that for the modern person, the bible served the same purpose as texts by the Stoics, Emerson, Goethe, and others. That is, they were aids to help individuals and communities know and create moral lives; Felix Adler, The Essentials of Spirituality (New York: Pott, 1905), 15.

${ }^{7}$ Walter Lippmann, "Public Opinion and the American Jew," American Hebrew (April 14, 1922): 575 .

8 "They [the churches] come down to us with a tradition that the great things are permanent, and they meet a population that needs above all to understand the meaning and the direction of change. No wonder their influence has declined, no wonder that men fight against the little influence they have"; Walter Lippmann, Drift and Mastery: An Attempt to Disguise the Current Unrest (Madison: University of Wisconsin Press, 1986), 93.

${ }^{9}$ The definitive biography of Lippmann is Ronald Steel's Walter Lippmann and the American Century (New Brunswick, NJ: Transaction, 1999). Steel deals extensively with Lippmann's intellectual relationships with the three men.

${ }^{10}$ Steel's preface, for instance, does not mention Lippmann's Jewishness, although he does discuss it in the body of the work, mainly in connection with Lippmann's childhood. Barry Riccio discusses Lippmann's Jewishness briefly, and then it is only to indicate Lippmann's discomfort with Jewish identity and distance from what he saw as Jewish concerns; Walter Lippmann: Odyssey of a Liberal (New Brunswick, NJ: Transaction, 1994), 1-2, 175.

${ }^{11}$ Adler's biographer's place him in the realms of religious thought and reform, in both American and Jewish contexts; Kraut, From Reform Judaism to Ethical Culture; Howard Radest,
} 
community throughout his life and held Ethical Culture lectures on Sundays to allow religious Jews to attend, Lippmann's contentious relationship with Judaism occasionally bordered on self-loathing. ${ }^{12}$ He refused to lecture to Jewish groups, turned down an award from the Jewish Academy of Arts and Sciences, and had very few Jews among his close interlocutors. Psychiatrist Carl Binger suggested that he feared any mention of Lippmann's Jewishness would jeopardize their friendship. His intellectual biographer Barry Riccio claims that "many of his friends never even knew he was Jewish." 13

No record indicates that Lippmann and Adler ever met, although they were both New Yorkers from 1911 until Adler's death in $1933 .{ }^{14}$ These men came from different backgrounds, ran in different circles, had very different relationships to their Jewishness, and had career trajectories that took them in quite different social and philosophical directions. Personally and professionally, they make odd bedfellows.

And yet the two spent much of their writing in the 1920s grappling with the same issue. They each deemed both tradition and transcendence to be inadequate sources of moral authority. Before the war, Lippmann had announced in a tone that was part celebration, part call to action: "Those who went before inherited a conservatism and overthrew it; we inherit freedom, and have to use it. The sanctity of property, the patriarchal family, hereditary caste, the dogma of sin, obedience to authority - the rock of ages, in brief, has been blasted before us." 15 Although his 1914 Drift and Mastery departed from his 1913 Preface to Politics in its break from muckrakers and socialists, it continued the assertion of a breakdown of tradition. Tradition had failed

Felix Adler (American Liberal Religious Thought) (New York: Lang, 1988). Texts on Reform Judaism in America often mention Adler and reactions to him. For a sample, see Nathan Glazer, American Judaism (Chicago: University of Chicago Press, 1998), 49-51; Dana Evan Kaplan, "Reform Judaism," in The Blackwell Companion to Judaism, ed. Jacob Neusner and Alan Avery-Peck (Oxford: Blackwell, 2003), 298; Michael Meyer, "American Reform Judaism and Zionism: Early Efforts at Ideological Rapprochement," Journal of Israeli History: Studies in Zionism 7 (Spring 1983): 49-64; Kerry Olitzky, Lance Sussman, and Malcolm Stern, eds., Reform Judaism in America: A Biographical Dictionary and Sourcebook (Westport, CT: Greenwood, 1993). Shaul Magid's forthcoming American Post-Judaism: Identity and Renewal in a Post-ethnic Society (Bloomington: Indiana University Press, 2013) likewise positions Adler in a tradition of Jewish thought about religious and cultural reform.

${ }^{12}$ In his founding address in 1876, Adler indicated that Ethical Culture was not a religion per se and therefore would not conflict with religious practice if participants still found ritual meaningful. "We propose to entirely exclude prayer and every form of ritual. Thus shall we avoid even the appearance of interfering with those to whom prayer and ritual, as a mode of expressing religious sentiment, are dear"; Felix Adler, "Founding Address" (New York: New York Society for Ethical Culture, 1876), 7.

${ }^{13}$ Riccio briefly discusses Lippmann's aversion to Jewish causes (as well as his own Jewish identity) in the context of Lippmann's disapproval of "tribal loyalty"; Walter Lippmann, 175.

${ }^{14}$ In addition, both lent their names as councilmen to the American Proportional Representation League, although it does not appear that either was particularly active in it. For one listing of the councilmen, see Proportional Representation Review 32 (October 1914): 14.

${ }^{15}$ Lippmann, Drift and Mastery, 16. In 1912 Lippmann had written in a similar vein, "The institutions of the past are like the fresh eggs of the past-good while they are fresh"; William Leuchtenberg, introduction to Lippmann, Drift and Mastery, 4. 
because it was simply no longer practical. Lippmann made this clear in his brief introduction to Drift and Mastery, where he suggests that life would be easier if we could simply rely on those who had come before us. If we had only to learn and embody tradition, "it would be easy." But, in his characteristically snappy tone, Lippmann wrote, "It might work on the moon." ${ }^{16}$ Having left behind the shackles of tradition, Lippmann explained, modern men were free to build their own convictions upon the great foundation of experience. His exuberance would wane, however, and he would question the ability of experience as the sole arbiter of morality.

Neither, however, was ultimately prepared to give in to utter moral relativism or nihilism. Indeed, after the war they saw the ill effects of unmoored morality in a multitude of social processes. Even before the war, Lippmann had tempered any enthusiasm for freedom from tradition with the grim realization that "we have lost authority. We are 'emancipated' from an ordered world. We drift." ${ }^{17}$ Adler wrote: "Should the idea of authority be preserved? I say yes. Should it be reinterpreted? I say likewise, yes." ${ }^{18}$ Although he referred more narrowly to parental authority, the sentiment provides a succinct statement of Adler's wider philosophy.

WAR

In the opening of his 1923 Hibbert Lectures, Adler warned: "The horror of the recent war is still felt in our bones, and yet it seems as if mankind could not take to heart the most drastic lessons, the most condign punishments. . . . Above all there is one fact that strikes every observer: the so-called moral forces seem to have failed in the great crisis through which the world is passing. Religion was powerless to stay the carnage." ${ }^{19}$ Americans, though wounded by the trauma, could not assimilate the gory lessons into their lives or future decisions; it seemed as though the war had taught them nothing. For Adler, the war had laid bare a grim fact: Americans' moral and ethical systems were not up to the task of making sense of and alleviating the horrors of armed conflict and death. Lippmann, too, expressed his deep disillusionment in the peace process and its indications of the larger pitfalls of a morality based in democracy and pragmatism.

Adler approached this crisis, like the rest of his thought, from a neoKantian framework. The self was autonomous, each person gave herself the moral law in concert with the rational, and each human was an end in herself. ${ }^{20}$ Authority, then, was interior, and could not be deduced from existing religious codes. He asserted: "The moral law is not derivative, it

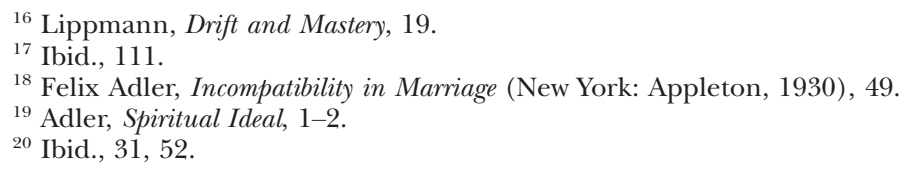




\section{The Journal of Religion}

cannot be proven, it cannot be denied." ${ }^{21}$ After the war had begun, but before the United States had entered, Adler warned against confusing civilization - of which religion and science were constitutive parts - with morality. Civilization was merely a means to moral life, and as such it could fail at the task. "Civilization, or the set of instrumentalities that serve the higher purposes of life, may continue to exist without any longer being used for higher purposes. The temples exist, but the religion that it taught in them becomes obsolete or obsolescent." ${ }^{22}$ He then asked, "What is wrong in our civilization as a whole, what deep flaw penetrates it to its core, what is the radical cause that has led to this universal strife?" 23 His answer was that imperial nations had mistaken instruments that constituted civilization for morality itself; the "temples" still stood, but they had lost their authority.

After the war, a darker tone crept into Adler's thought, and he talked of "spiritual pain" and witnessing fellow human beings "stretching forth their arms, sinking, drowning, and we are powerless to assist them." ${ }^{24}$ Adler wrote of postwar American society: "The time has come to reconstruct the moral ideal with a view to giving it the power it lacks to grip men's wills and more adequately control their behavior." ${ }^{25}$ Such a significant power to "grip" men's wills could only come from inside. Traditional religions had lost this grip because their tenets were no longer plausible in the face of science and crises like the war. Instead of calling on men to stop fighting, Christianity, Judaism, and Islam had all become caught up in ideals external to their essences and consequently encouraged the carnage, in Adler's view. ${ }^{26}$

But it would be unfair to characterize Adler as focusing on the interior self at the expense of interpersonal interaction. Whereas a traditional Kantian might say that one person could be moral or ethical in isolation, for Adler, persons could only come into the fullest sense of morality through human interactions. This dimension of his thought helps to frame why the war was so disheartening for him: both the war itself and its aftermath represented

${ }^{21}$ Felix Adler, Creed and Deed: A Series of Discourses (New York: Putnam \& Sons, 1880), 80.

${ }^{22}$ Felix Adler, The World Crisis and Its Meaning (New York: Appleton, 1915), 114. Science, for Adler, had begun to be used as an instrument of militarism, violence, and immorality and facilitated the atrocities of war. In this, what should have been the tool of science had been mistaken for its own source of authority and its own end. See especially the title essay in World Crisis.

${ }^{23}$ Ibid., 120. Adler's ultimate answer to these questions was that powerful western nations (especially Germany and Great Britain) had mistaken civilization for morality and therein justified the subjugation of "weaker races" and territories (120-45).

${ }^{24}$ Adler, Spiritual Ideal, 11.

${ }^{25}$ Ibid., 111.

${ }^{26}$ Given its marginal place in American philosophy, it is surprising that Adler gave Islam a place in his list. Perhaps in part because he sought to demonstrate the helplessness-and even complicity - of all religions in the face of the war, Islam could serve as a negative example. "Indeed, many of [religion's] representatives fell in with the prevailing fury, and on their part added fuel to the flames. Allah is said to have laughed aloud in his Mohammedan heaven when the news came that Christian preachers on the one side were proclaiming a Jehad or a holy war against their Christian brethren on the other side" (ibid., 2). 
international interaction in an unprecedented, widespread, and visible way. After the war, he called for the formation of a "group morality," calling it one of the "needs of our own generation." 27 Like Lippmann, he insisted on the importance of experience as the testing ground of morality (although both thought that experience alone was inadequate). For him, the social or collective sphere was the "laboratory" for the shaping of morality. ${ }^{28}$ The trauma of the violence, the disappointment of the League of Nations, and the subsequent concern about the failure of Wilsonian idealism all served as outsized examples of the current conception of moral authority's failure in interpersonal realms. For Adler, the solution was the relocation of moral authority to the individual, although one dimension of that authority was always outwardly directed.

Lippmann, too, experienced profound disillusionment in the face of the outcome of war, the Treaty of Versailles, and the United States' refusal to join the league. (Lippmann's disillusionment was personal as well as philosophical: he was one of Wilson's advisors and had helped draft his Fourteen Points speech.) These events forced Lippmann to reevaluate the Jamesian pragmatism which he had earlier espoused. Whereas in his early career, he had faith in the ability of individuals and collectivities to progress by experience, he began to see the possible pitfalls of such a system. ${ }^{29}$ Widespread experience or a democratically forged consensus could still be wrong or damaging, as he made clear in his 1926 "Dogma of Majority Rule." ${ }^{30}$ Expert opinion was still opinion. He nevertheless remained an elitist and technocrat, and believed that expert opinion, though not foolproof, was still superior to that of the masses. In his 1922 Public Opinion, he complicated his former pragmatist philosophy by suggesting that what might seem like experience was not always pure. The press and the media in general could "manufacture" opinions or consent. ${ }^{31}$ The same text brought the term "stereotype" into common usage to describe the masses' process of social cognition. But he did not

${ }^{27}$ Ibid., 47.

${ }^{28}$ Felix Adler, An Ethical Philosophy of Life: Presented in Its Main Outlines (New York: Appleton, 1925), 341. The language of experiment and experience also reflects the influential work of John Dewey, who was a colleague of Adler's at Columbia University.

${ }^{29}$ Although very early in his career, his work bore the mark of his teacher William James most strongly, as time went on, he gravitated more toward George Santayana's philosophy. James's idea of the experiential process of arriving and truth and morality struck Lippmann more and more as moral relativism, and he began to seek a morality that could be grounded beyond individual human experience and nevertheless harmonious with it. For a more indepth account of this phase of Lippmann's thought, see Ronald Steel's magisterial biography, Walter Lippmann and the American Century, 12-32.

${ }^{30}$ Lippmann explains the "primitive intuition of democracy" as "any opinion, any taste, any action was intrinsically as good as any other. Each stands on its own bottom and guarantees itself. If I feel strongly about it, it is right; there is no other test. There is no arbitrament by which the relative value of opinions is determined. . . Since no value can be placed upon an opinion, there is no way in this philosophy of deciding between opinions except to count them"; Walter Lippmann, "Dogma of Majority Rule," in Men of Destiny (New York: Macmillan, 1927), 45-60, quotation at 54.

${ }^{31}$ Walter Lippmann, Public Opinion (New York: Harcourt, Brace, 1922). 


\section{The Journal of Religion}

abandon pragmatism wholesale; in fact, he thought its methods of testing could prove an important critique of those individuals who portrayed themselves as ethical authorities. In Preface to Morals, he wrote: "The moralist is irrelevant, if not meddlesome and dangerous, unless in his teaching he strives to give a true account, imaginatively conceived, of that which experience would show is desirable among the choices that are possible and necessary." 32 The teaching of anyone claiming to be a moralist should be subjected to the experiential scrutiny of pragmatism, not evaluated within some disembodied and acontextual system.

In the wake of the war, Lippmann began to incorporate more of the thought of his teacher George Santayana into his philosophy. Lippmann held ideals derived from natural experience, not supernatural dicta, and people create or hold onto these desires because of an aesthetic need to make sense of the universe. Perhaps taking to heart Santayana's aphorism that "only the dead have seen the end of war," Lippmann crafted an account of the moral that would function in all worlds and contexts, not only an ideal one. But this did not mean that locating the pragmatic moral process within individuals doomed society to repeat its mistakes. Nor did it mean that the moral man would be aloof. Combining James, Santayana, and Aristotle, ${ }^{33}$ Lippmann explained that modern Americans would grapple with their existential yearning for meaning by training themselves to engage virtuously with the world around them. He wrote: "They have, therefore, to reeducate their wants by an understanding of their own relation to a world which is unconcerned with their hope and fears." 34

Lippmann articulated what he called "the schooling of desire." 35 As the suffering of war and the manipulation of mass media continued to engulf modern life,$^{36}$ the serious person could no longer go on blithely believing in a father-figure God, his short list of rules, or his assurance that the world was really an orderly and meaningful place. Therefore, Lippmann wrote, modern man "can no longer count on possessing whatever he may happen to want. And he must therefore learn to want what he can possess." 37

In his earlier years, Adler had tended toward optimism. He was progressive both as a general philosophy of history and a specific political project. But as the 1910s closed and the 1920s wore on, he began to lose patience with "mere" reform and to espouse a darker account of the human condition. ${ }^{38}$

\footnotetext{
${ }^{32}$ Lippmann, Preface to Morals, 319.

${ }^{33}$ Although he does not credit Aristotle, Lippmann's account of how one "schools" her desires has significant elements of Aristotelian ethics.

${ }^{34}$ Lippmann, Preface to Morals, 320-21.

${ }^{35}$ Ibid., 311.

${ }^{36}$ Lippmann articulates this idea of manipulation and "the manufacture of consent" most fully in Public Opinion, 248-52.

${ }^{37}$ Ibid., 192.

${ }^{38}$ Adler's biographer Howard Radest has called it "almost existentialist" in tone and content. "Felix Adler," in The Dictionary of Modern American Philosophers, ed. John Shook (London: Thoemmes Continuum, 2005), 28.
} 
Lippmann's thought had been a mix of optimism and pessimism, romantic idealism and realpolitik, especially in his younger years. Yet especially in the years immediately following the war, he, like Adler, found his social and political critique taking on the tone of disillusionment. Adler and Lippmann agreed on two fundamental points: society must have structure, and the interpersonal self is the root of society. But the war had demonstrated the instability of that structure and the profound volatility and fallibility of interpersonal selves. The social changes associated with women's rights would do the same.

\section{WOMEN}

As both the war and women's rights movements showed, in moral authority's move from heaven to earth, the autonomy and chaos had become inextricably linked. In this way, Lippmann and Adler's pessimism stemmed from the same source as their optimism: humans could reconfigure moral authority, but because they could, moral authority could never again be fixed. As he saw both structures disintegrating, Lippmann created a strong analogy between the father as the head of the household and traditional monotheism: nuclear families had functioned "to make credible the idea that above the child there is the father and above the father a king and the wise men, above them all a heavenly Father and King. It is plain that any change which disturbs the constitution of the home will tend profoundly to alter the child's sense of what he may expect the constitution of the universe to be. There are many disturbing changes of which none is more important surely than the emancipation of women." When children no longer saw the father as the king of the household, they would no longer be inclined to see God as the king of the universe, Lippmann averred: traditional notions of God become "less and less credible as women assert themselves. The child of the modern household is soon made to see that there are at least two persons who can give him orders, and that they do not always give him the same ones. This does not educate him to believe that there is one certain guide to conduct in the universe." In short, overturning of women's dependence on husbands was not "conducive to belief in authority." 39

For Lippmann, like war, the emancipation of women threw into sharp relief the crisis of authority. International relations, a global scene for politics, and mass media had turned enclave societies into hubs of communication. Women, as they were thrust from the home into the public sphere, would experience this change all the more drastically. "I have tried to suggest what this change from a world of villages has meant for politicians, clergymen, and social thinkers. Well, for women, the whole problem is aggravated because

\footnotetext{
${ }^{39}$ Lippmann, Preface to Morals, 90-91.
} 
they come from a still smaller world and a much more rigid authority." ${ }^{40}$ If men experienced a transition from small, relatively isolated societies or nations to international stages, women were torn from the home and thrust upon those sprawling new stages.

In his 1914 Drift and Mastery, Lippmann had warned that women would soon confront the same existential problems as men had: "The emancipated woman has to fight something worse than the crusted prejudices of her uncles; she has to fight the bewilderment in her own soul. She who always took what was given to her has to fend for herself. She who passed without a break from the dominance of her father to the dominance of her husband is suddenly compelled to govern herself. Almost at one stroke she has lost the authority of a little world and has been thrust into a very big one, which nobody, man or woman, understands very well." 41 The swift transition of the social position of women - from dependent to autonomous individualmirrored the slower transitions of modernity for all people. The bewilderment of her soul would recapitulate the hollow feeling that had been creeping up on men. The acids of modernity that had eaten through the fabric of past moral authorities would leave women adrift, just as they had men.

Although he was in favor of women's rights and suffrage, Lippmann thought that feminists had identified the wrong site of their discontent. Autonomy, which they requested in the form of rights, would itself be the source of alienation, confusion, and a feeling of groundlessness. Upon becoming emancipated, women would find what Lippmann already knew: becoming one's own moral authority could be alienating and confusing. "When she begins to prescribe for herself, her problems begin," 42 he wrote. Along with the "brave and brilliant atheists who have defied the Methodist god and have become very nervous," he lamented with characteristic irony, "the women who have emancipated themselves from husbands, fathers, and homes, and with the intermittent but expensive help of a psychoanalyst, are now enjoying careers as interior decorators." 43 The independence that had seemed so desirable would in reality turn out to entail a feeling of precariousness and an existence without grounding, he warned. Like those who "bravely" abandoned their religion suddenly to find themselves living an unmoored existence, these women would experience the darker side of autonomy.

Furthermore, these changes for women in turn signaled changes in society at large. He noted two particular factors, "women's economic independence and birth control," 44 that had moved women closer to social locations that allowed for self-determination. In both matters, he was moderate. More than

${ }^{40}$ Ibid., 219.

${ }^{41}$ Lippmann, Drift and Mastery, 218-19.

${ }^{42}$ Ibid., 214.

${ }^{43}$ Lippmann, Preface to Morals, 6.

${ }^{44}$ Ibid., 93. 
being wholeheartedly enthusiastic about the prospect, Lippmann simply treated women's emancipation as if it were inevitable; he preferred to evaluate the effects he anticipated rather than offering his opinions on whether or not the women's movement should achieve its ends. "To insist that women need to be moulded by authority is a shirking of the issue. For the authority that has moulded them is passing." ${ }^{45}$ Some of the results of this inevitability would be positive, but he thoroughly disliked other effects he anticipated. He lamented that women could or would work outside the home, for instance. When he spoke of women's "careers," he often meant the idea of homemaking as a domestic science, in line with other reformers and progressives of the era. He opposed the legalization of the dissemination of birth control on the grounds that doctors and nurses should be the only ones to convey such information. ${ }^{46}$ In becoming less differentiated from men, women also reconfigured the family. Children would see not one authoritative figure-in Lippmann's view, an easy analogy for monotheism-but two independent beings. The loss of the image of the family as analogous to humans' relationship to God would exacerbate the receding credibility of traditional religion for the next generation.

In 1915, he wrote in a letter to the feminist Marie Jenny Howe, "In a rough way one might describe feminism as a virtue made out of a necessity. Women have to readjust their lives. The compulsion has made them dream various ideals. They have pictured themselves as self-governing, self-respecting members of a free community." This necessity was the disappearance of the traditional ordering of gender roles. "In other words," Lippmann continued, "the emancipation of women, which is at bottom the dumb product of social conditions, becomes in a small minority a self-conscious purpose. Women come to desire what they are compelled to be." Forced to abandon structures of authority, some women would convince themselves that freedom from those structure was exactly what they desired. But Lippmann imagined that the result for these women would not be happiness nor fulfillment because "desires, theories, ideals always run ahead of the facts, and a good part of the time they run directly against the grain of the facts. ${ }^{17}$ Lippmann explained, "Women have to live differently. Yet society is not decently ordered so they can live differently. They go into industry because they are compelled to, but they find that industry is not conducted so they can live sanely within it." For Lippmann, the transition into industry presented another case of what he

\footnotetext{
${ }^{45}$ Lippmann, Drift and Mastery, 125.
}

${ }^{46}$ Letters to Mary Ware Dennett, February 4, 1916, and February 14, 1916, in John Morton Blum, ed., Public Philosopher: Selected Letters of Walter Lippmann (New York: Ticknor \& Fields, 1985), 36-37. Here Lippmann is aligned with Progressives - most famously Margaret Sangerwho lobbied for reforming laws that would allow doctors (but not others) to disseminate information about birth control.

${ }^{47}$ Letter to Marie Hoffendahl Jenny Howe, February 16, 1915, in Blum, Public Philosopher, $20-21$. 


\section{The Journal of Religion}

had identified in Drift and Mastery: women had "been the great routineers," 48 but with the passing of traditional modes of authority they would no longer be. The experience of these women epitomized the drift that affected the whole society: "Women are discovering . . . that there is a great gap between the overthrow of authority and the creation of a substitute." ${ }^{49}$ This gap represented a void not only in the social structure, but also within the individual. Lippmann diagnosed the "spiritual problem[:] We have lost authority. We are 'emancipated' from an ordered world. We drift." ${ }^{50}$ Drift and autonomy were blood brothers.

Felix Adler offered a related diagnosis of modern malaise. Men already experienced these existential difficulties, and women would only compound their own troubles by seeking out similar rights. He characterized the malaise as a threefold problem: the widespread "sense of insignificance . . . in this wide universe," the seemingly senseless suffering of the innocent, and the problem of the "divided conscience." In a typical example of this line of reasoning, Adler explained his position on "woman suffrage" in a 1909 lecture, "I believe things are not what they seem. The ballot in the hands of men is not doing what it should, and I would not like to have the evil we now suffer increased by millions and millions of voters unprepared to exercise suffrage." ${ }^{52}$ Several years later, he opined, "The misfortune of the women's movement is that they have imitated men too much." ${ }^{53}$

Women, Adler averred, are not the same as men, and current trends to mistake them as such were spreading the ill: "Again, there should be warning against an idea which is very common at present, under the influence of the college education of girls and the emancipation of woman - the idea that in the relation between the sexes, every attempt should be made to ignore sex difference, and that men and women should meet just as men meet with men, on the basis of comradeship. This idea I believe is, like that of romantic love, a pernicious one." ${ }^{54}$ Treating the like as unlike - that is, treating women as men-would only lead to the spread of men's problems rather than the alleviation of women's problems.

The reasons for Adler's fears lay in his assumptions about the essence of women and their role in society. He explained: "She is the factor of integration in human society as man chiefly is the factor of differentiation." ${ }^{55}$ Like Lippmann, who mocked the woman who "emancipated" herself from "husband, father, and home," Adler saw women's rights as a drive toward an individual autonomy that would have isolating consequences. Lippmann saw

${ }^{48}$ Lippmann, Drift and Mastery, 124.

${ }^{49}$ Ibid., 126.

${ }^{50}$ Ibid., 111.

${ }^{51}$ Adler, Spiritual Ideal, 13-27.

52 "Felix Adler on Woman Suffrage," New York Times, November 8, 1909

53 “Women's Part in Life as Dr. Adler Sees It," New York Times, January 13, 1913.

${ }^{54}$ Felix Adler, Marriage and Divorce (New York: McClure, Philips, 1905), 20.

${ }^{55}$ Adler, Incompatibility in Marriage, 32. 
these consequences as most significant for individual women, who would soon find that autonomy was not all they had imagined, whereas Adler worried that if women became like men, then the world would be increasingly a collection of individuals without social cohesion. Because American women were becoming politically, economically, and vocationally more like men, according to Adler, the crisis of moral authority would become only more acute.

\section{PESSIMISM AND PROGRESS}

The locus of moral authority was not an idle question for Adler and Lippmann. It informed the most pressing issues of their day. The issues of early twentieth-century America certainly differed from those of the rabbinic sages, but the midrash about Eliezer and Joshua suggests that locating moral authority has been a perennial question in the tradition. Its dark postscript illustrates the high stakes. Once the heavenly voice had spoken and capitulated its authority to the rabbis, the other sages shunned Eliezer. They burned everything he had ever declared pure, and they excommunicated him. That day Rabban Gamliel, the leader of the rabbinic group that had shunned Eliezer, was sailing, and an enormous wave loomed up and nearly drowned him. He recognized it as a threat of punishment for his part in the shaming of Eliezer, who also happened to be his brother-in-law. Ima Shalom, Gamliel's sister and Eliezer's wife, recognized the precariousness of the situation. She knew that if Eliezer prayed about the shame and hurt he had experienced because of his excommunication, Gamliel would die. The wave had already nearly killed him. So she prevented Eliezer from praying as long as she could. One day, though, she brought bread to a beggar at the door, and returned to find Eliezer pouring his heart out to God. At that moment, she knew her brother Gamliel would be dead. Ima Shalom, it seems, saw the simultaneous power and instability that an earthly moral authority entailed.

If the Torah is not in heaven, and moral authority resides on earth, the stakes, as Lippmann and Adler knew well, are high. Eliezer, who was technically correct in his halakhic decision, was excommunicated and grieved. Gamliel died for his part in the shaming. All this suffering resulted from a case in which the men followed the proper decision-making procedures of the study house. The episode demonstrates that a community creating and following social rules would not constitute an answer in itself. Moral authority may have lain with the rabbis, but as a result it gave them the tools to rend their community asunder.

If men sought to find or create a moral authority, they might have looked beyond themselves, such as the way that both Adler and Lippmann had characterized Judaism and Christianity. They each wrote that Hebrew religion and the stories of Jesus had provided role models and valuable rules and had been functional- even fulfilling - for premodern societies. But instead of positing an authority beyond the self, Lippmann and Adler described a moral 
authority within the self. To be sure the neo-Kantian Adler and pragmaticleaning Lippmann differed in their prescriptions for a moral society, but their diagnoses converged. Tradition and transcendence had both outlived their usefulness and ability to compel humans. Pragmatism would claim that experience should be the arbiter, and Kantianism would claim the sovereign individual armed with his categorical imperative. But Lippmann had become convinced of the pitfalls of the subjective criteria of experience, while Adler critiqued Kantianism for ignoring interpersonal and experiential aspects of the human condition. Both turned to an account of the individual, deeply embedded in culture, as the place to ground moral authority. This interior moral authority, which would be largely guided by experience, was anything but foolproof. In fact, it needed to act and exercise itself in order to improve.

Lippmann and Adler both saw the possibilities - even inevitabilities - of the errors and suffering that would occur in the high-stakes wager of locating moral authority within human selves. If moral authority rested in human individuals and the societies they made, then moral and ethical faults also fell squarely on those humans and their societies. No appeals to the mysteries of a god's ways could explain conflict or death. Neither was enormously optimistic about some immediate or revolutionary change, but both believed in the possibility of progress. At least the war, women's rights, and the disillusionment of the 1920s had outlined their crisis.

So how could both men have such faith in progress, when they saw such darkness in the culturally created people around them? They both bought into the popular "scientific" narrative of general human progress from one age to the next, and from the savage to the civilized. ${ }^{56}$ They also believed that the evaluative process of pragmatism would slowly improve moral functioning, not only within each individual, but among and between social groups. Lippmann and Adler rejected an "each man is an island" type of autonomy, instead insisting that moral authority could dwell within the self, but that self was always a social self, forever relating to others. If personal morality could improve, then social morality would follow in time. The path to improvement, however, would be paved with missteps and suffering, the inevitable results of testing and continually recreating a human morality. But without recognizing humanity as the locus of moral authority, the rest of history would be doomed to repeat crises like the war and the darker side of women's emancipation without learning from the experiences. ${ }^{57}$ In the end, both the progress and the suffering would be the results of a single observation: the Torah is not in heaven.

\footnotetext{
${ }^{56}$ Thinkers as diverse as Freud, George Beard, and G. Stanley Hall all espoused varieties of this narrative in psychological, developmental, anthropological, and other forms.

${ }^{57}$ This viewpoint reflects Lippmann's debt to Santayana. Although a fascination with history permeates much of Santayana's thought, his reflections are perhaps most articulated in Dominations and Powers: Reflections on Liberty, Society, and Government (New Brunswick, NJ: Transaction, 1995), which he began writing during the first World War, set aside for thirty years, and returned to during World War II, as he describes in his introduction to the volume.
} 